\title{
SEASONALITY OF REPRODUCTION IN THE WILD BOAR
}

\author{
R. MAUGET \\ C.N.R.S. Centre d'Etudes Biologiques des Animaux Sauvages, \\ Villiers-en-Bois, 79360 Beauvoir-sur-Niort, France
}

In the management of large breeding units of domestic pig, particular attention is currently paid to seasonal fluctuations in reproductive performance. Although the domestic pig is known to reproduce throughout the year, there is a seasonal decrease in breeding performance. Considerable reproductive inefficiency has been reported during the summer and autumn months in the domestic sow in France (Corteel, Signoret and du Mesnil du Buisson, 1964), England (Stork, 1979), Italy (Enne, Beccaro and Tarocco, 1979), USSR, (Radev, Andreev and Kostov, 1976), USA (Hurtgen, 1976; Hurtgen, Leman and Crabo, 1980) and Australia (Paterson, Barker and Lindsay, 1978). Although not exhaustive, this list shows the general trend. The European wild boar represents the wild form from which the modern breeds of domestic pig have been derived by intensive selection directed towards growth and productivity criteria. However, most studies of the European wild boar have been conducted from an ecological or hunting viewpoint (Oloff, 1951; Haber, 1969; Snethlage, 1974). The aim of this chapter is to review our knowledge of the reproductive biology of this wild species as a basis for comparison with the domestic pig.

Most of the data presented here were obtained from an indigenous population of wild boar living in a natural environment, the Chize forest in midwestern France. They form a part of a study dealing with the ecological, behavioural and physiological (reproductive) aspects of the adaptation of the wild boar to its environment (Mauget, 1980).

\section{Reproductive performance}

Compared with other ungulates of similar body size, the wild boar appears to be the species having the highest reproductive capacity. This characteristic, associated with a great faculty of adaptation, seems likely to be at the origin of domestication, the result of which has been to optimize productivity.

\section{FREQUENCY OF BREEDING}

Generally one litter is produced each year with farrowing occurring in late winter and early spring. However, under certain conditions, which will be considered later, a second farrowing in the year may occur. 


\section{LITTER SIZE}

Information has been obtained from the reproductive tracts of 57 slaughtered females in which the foetuses were examined. There were, on average, $4.60 \pm 0.18$ foetuses per sow. Variations from one year to another were not statistically significant. However, variations were observed in the litter size in relation to the weight and subsequently to the age and parity of the female. Average litter size varied from $2.50 \pm 0.51$ for young primiparous females (weighing $30-39 \mathrm{~kg}$ and 9-15 months of age) to $5.43 \pm 0.26$ for older females (weighing more than $80 \mathrm{~kg}$ and over 3 years of age).

\section{OVULATION RATE AND FOETAL SURVIVAL}

The number of ova shed per female was determined by corpora lutea count. Ovulation rate for the combined mature female age group was $5.26 \pm 0.25(n=31)$, with a $12.5 \%$ intrauterine loss.

\section{CONCEPTION RATE}

Conception rate (the percentage of mature females which are bred) varied considerably among the weight-age classes. Thus in the primiparous females (30-39 kg, 9-15 months) the maximum conception rate was $68.8 \%$ ( $n=52$ females). It reached $97.9 \%(n=48)$ for animals weighing $40-59 \mathrm{~kg}$ and aged 16-24 months and $100 \%(n=53)$ for pigs of $60 \mathrm{~kg}$ and more and over two years of age.

\section{GESTATION LENGTH}

The gestation period of wild females reared in enclosures was $119 \pm 0.7$ days $(n=18)$ with a range of $112-126$ days.

Table 24.1 gives a comparison of the reproductive performance established in the wild boar with that of the domestic pig and feral pigs (i.e. domesticated animals returned to a wild status). While modern breeds of domestic pig may have a litter size as high as 20 , with a mean value of about 12 , the wild boar averages only 4.6 young. However, the intrauterine mortality which reaches $30 \%$ in the domestic sow, is significantly lower in the wild pig. In feral pigs, ovulation rate is intermediate between the other two but intrauterine losses still remain high. Mean gestation length appears slightly higher in the wild pig than in the domestic sow. While it is clear that the wild boar differs in reproductive performance from domestic forms, the essential characteristic of its reproduction is its seasonal pattern.

\section{Season of breeding}

In pure breeds of wild boars having no history of hybridization with domesticated animals, as assessed by chromosomal studies (McFee, Banner and Rary, 1966; Mauget et al., 1977), reproduction is clearly seasonal. 


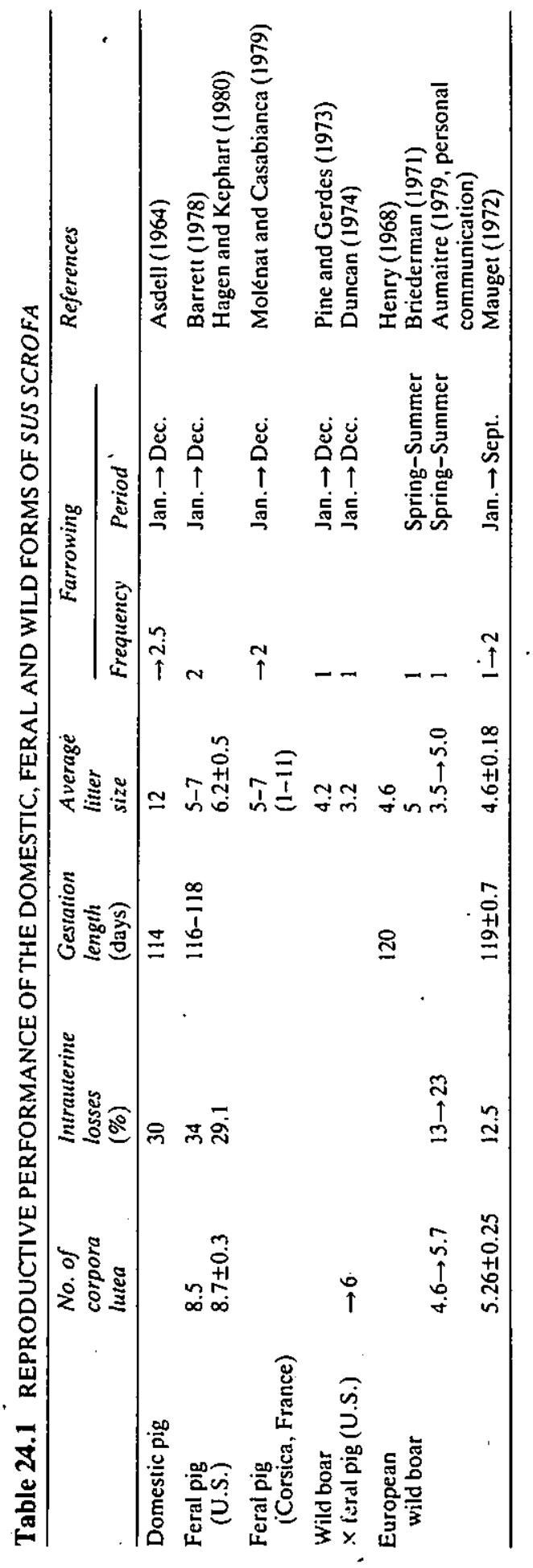



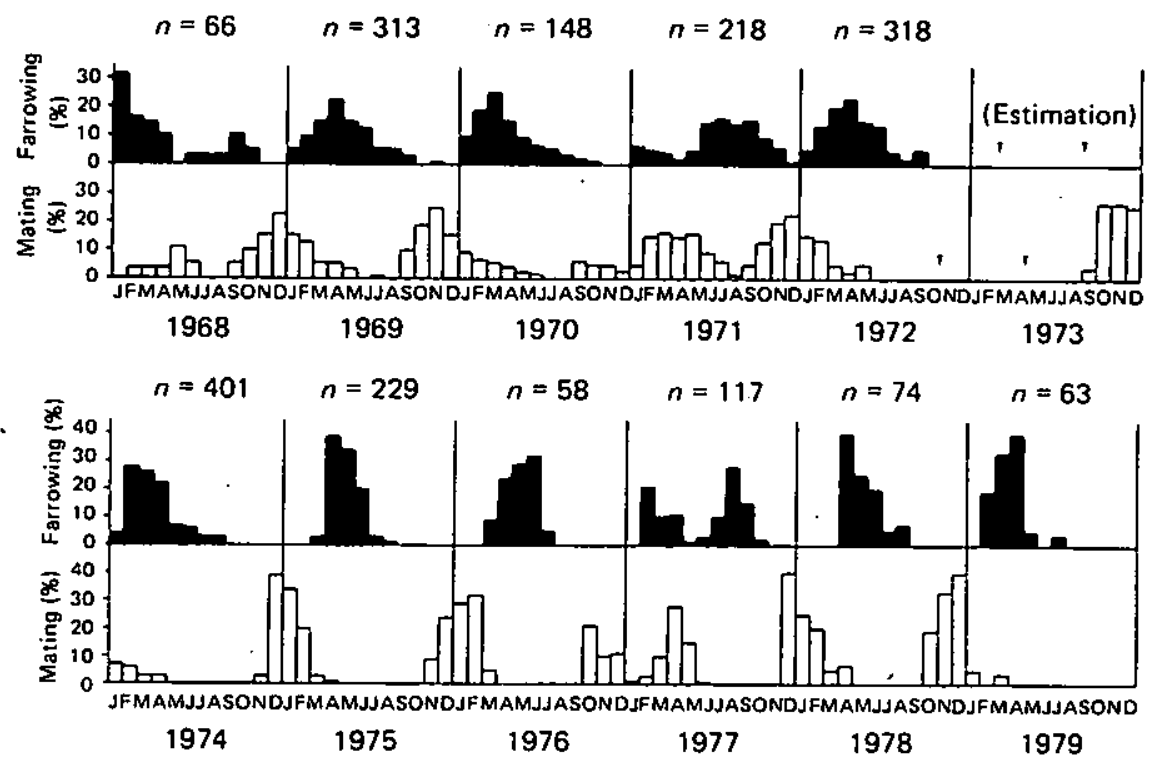

Figure 24.1 Monthly distribution of farrowings and matings recorded in the Chize forest from 1968 to 1979, expressed as the percentage of total annual number $(n)$ of observations

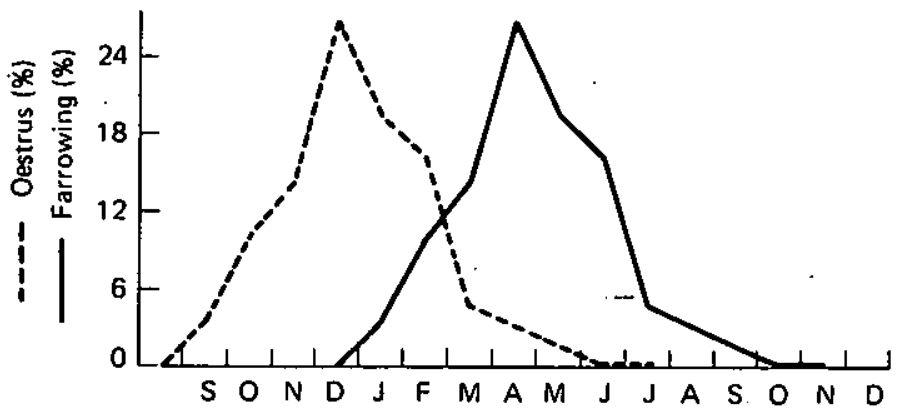

Figure 24.2 Unimodal distribution of farrowings and corresponding oestrus (pooled data from seven years, estimated by back-aging dates of birth of 1584 young).

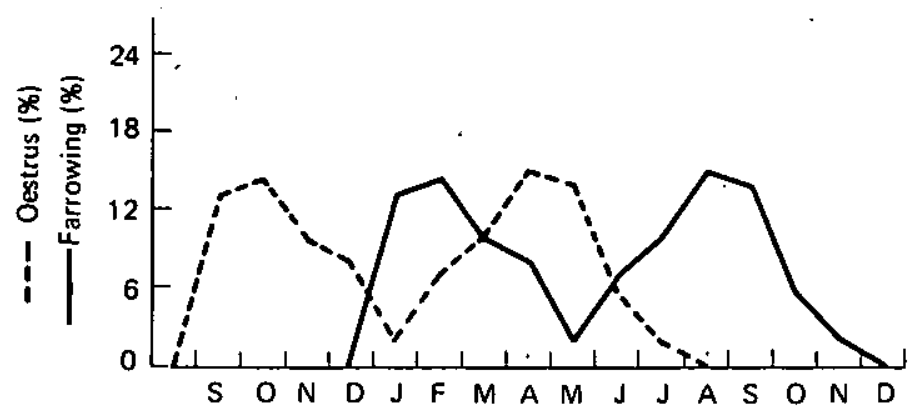

Figure 24.3 Bimodal distribution of farrowings and corresponding oestrus (pooled data from three years, estimated by back-aging dates of birth of 401 young). 


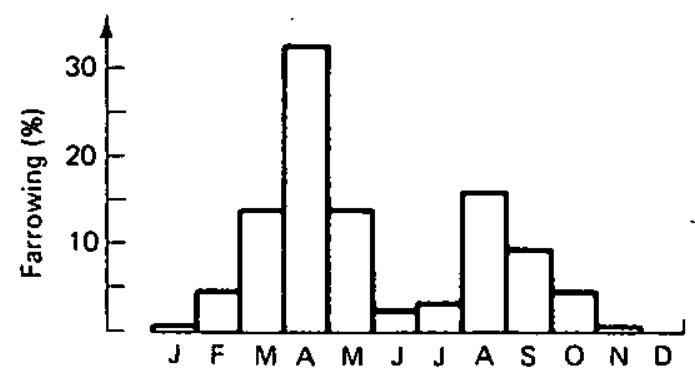

(a)

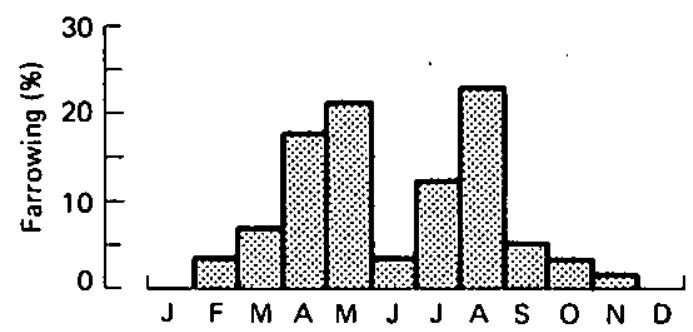

(b)

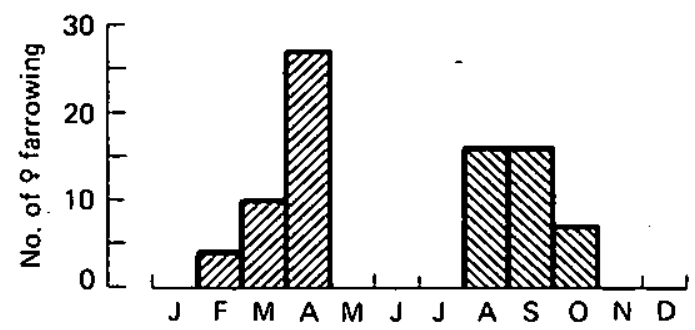

(c)

Figure 24.4 Farrowing data of wild boars in the commercial rearing unit. (a) Whole population $(n=226)$; (b) females reaching puberty $(n=56)$; (c) females farrowing twice a year, $\mathbb{Z}$ first litter; $\mathbb{S}$ second litter

Analysis of farrowing data recorded both in forest and in enclosures supports the evidence of such seasonal breeding (Mauget, 1978).

The monthly distribution of farrowings and corresponding oestrus observed in the population of the Chize forest from 1968 to 1979 are presented in Figure 24.1 and show considerable variation. There appear to be two types of farrowing distribution. One is unimodal (Figure 24.2) with the peak of farrowing occurring in April and May and a wide distribution ranging from. January to September. In the bimodal type (Figure 24.3), two peaks are seen. The first peak occurs in January and February and the second one in August and September. It is interesting to note that in years with two periods of birth the peak occurs before the unimodal one.

The animals involved in each breeding period can be determined from data collected in enclosures on individually marked animals (Figure 24.4). 


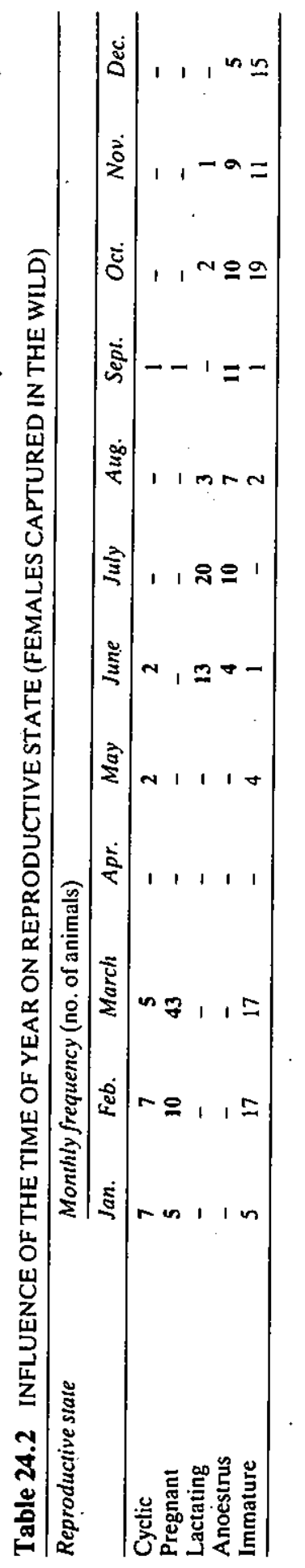


The histogram of the monthly distribution of births recorded in a rearing unit is typically bimodal as shown in panel (a); the first peak is in April followed by a second in August. The animals involved in these two main periods are young females reaching puberty at one of the peaks (panel (b)) and adult females farrowing twice a year (panel (c)). The second litter in the year is obtained as a result of the separation of the sow from her young three weeks after parturition.

\section{Annual cycle of ovarian activity}

Farrowing distribution results from seasonal ovarian activity and on the basis of samples collected all year round in the forest, an anoestrous period occurs during the summer and autumn months.

Reproductive tracts from female wild pigs were examined to determine their physiological state. Five reproductive states could be distinguished: cycling, pregnancy, lactation, anoestrus and immature. The histological characteristics of ovaries and vaginal epithelium corresponding to each stage agree with the morphological descriptions classically reported in the domestic sow (Corner, 1921; Bal, Wensing and Getty, 1969; Steinbach and Schmidt, 1970). Reproductive states varied at different times of the year (Table 24.2). The occurrence of anoestrus in females was seen as early as June and as late as December.

Table 24.3 PLASMA PROGESTERONE LEVELS (MEAN \pm 2 S.E.M.: 95\% CONFIDENCE LIMITS) ESTIMATED ON FEMALE WILD BOARS IN DIFFERENT REPRODUCTIVE STATES

\begin{tabular}{lll}
\hline Reproductive state & No. of females & $\begin{array}{l}\text { Plasma progesterone } \\
(\mathrm{ng} / \mathrm{ml})\end{array}$ \\
\hline Cyclic & 11 & $12.47 \pm 2.07$ \\
Pregnant & 17 & $13.45 \pm 0.73$ \\
Lactating & 30 & $3.95 \pm 0.51$ \\
Anoestrus & 37 & $2.19 \pm 0.25$ \\
Immature & 13 & $3.20 \pm 0.65$ \\
\hline
\end{tabular}

Plasma progesterone levels related to the various reproductive states are shown in Table 24.3. Both cyclic and pregnant animals had high mean progesterone levels. In animals with no functional corpora lutea, progesterone levels were somewhat higher when compared with the basal levels generally reported in domestic sows (about $1 \mathrm{ng} / \mathrm{ml}$ ). A stress-induced adrenal secretion of progesterone could be envisaged in such trapped wild animals.

In order to determine precisely the timing of ovarian function, longitudinal analysis was performed on adult females older than eighteen months of age which had been captured in the wild and maintained in enclosures without males. From weekly bleeding, the evolution of plasma progesterone concentration as a reflection of ovarian activity was determined. Marked seasonal variations in weekly mean values were observed (Figure 24.5). From December and January to June and July, progesterone levels were high. The weekly mean values were associated with standard errors 


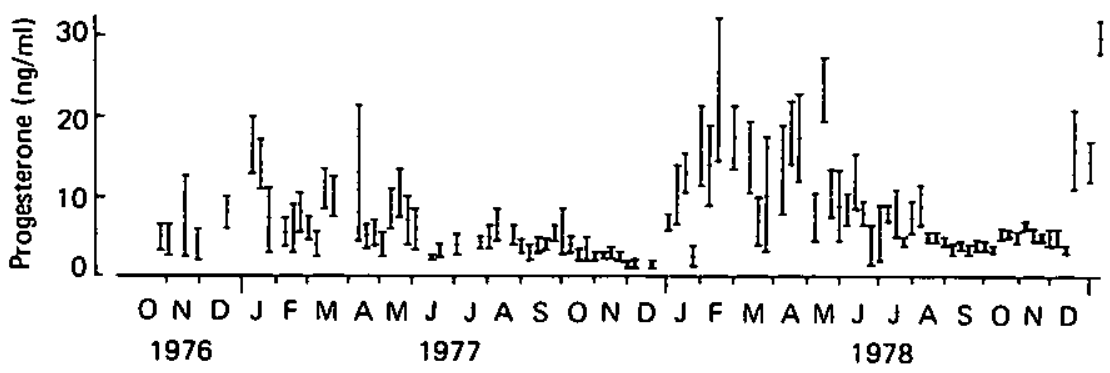

Figure 24.5 Seasonal variations of plasma progesterone levels in unbred adult female wild pigs (mean \pm S.E.M. based on weekly values from six animals)

which reflected a wide range in individual progesterone levels in relation to cyclic ovarian activity. They varied from $3-4 \mathrm{ng} / \mathrm{ml}$ to $20-30 \mathrm{ng} / \mathrm{ml}$ with a mean of $13.45 \mathrm{ng} / \mathrm{ml}$. These values are in agreement with those that have been reported during the oestrous cycle in the domestic sow (Stabenfeldt $e t$ al., 1969; Tillson, Erb and Niswender, 1970; Edqvist and Lamm, 1971; Henricks, Guthrie and Handlin, 1972; Shearer et al., 1972). However, the basal levels appear somewhat higher and as discussed above, the adrenal cortex might contribute to this. Time series analysis (the method of Halberg $e t$ al., 1972) has revealed a cyclicity of progesterone level ranging from 19-23 days. This periodicity is comparable to the length of oestrous cycle determined by Henry (1968) in penned female wild pigs monitored for oestrus and is within the range of values for the domestic sow. During the summer and autumn months progesterone concentrations remain at a low level characterizing an anoestrous stage. Thus, a regular alternation of ovarian cyclic activity and anoestrous sequences appeared over the 28 months of this study.

\section{Environmental involvement}

It is a general feature of wild mammals that environmental factors may influence the seasonal breeding activity (see reviews by Perry and Rowlands, 1973; Assenmacher and Farner, 1978; Mauget, Boissin-Agasse and Boissin, 1981). The seasonal synchronization of sexual activity might result from the adjustment of an 'endogenous oscillatory system' (Assenmacher, 1974) by cyclic environmental factors. It is established that for numerous species natural photoperiodism is the main synchronizer (Menaker, Takahashi and Eskin, 1978). However, other environmental factors (climatic, nutritional and social) might be involved in the timing of seasonal breeding.

\section{NUTRITIONAL FACTORS}

Under the controlled conditions of rearing, food is exclusively supplied by man. From data recorded on 53 wild boar rearing units it appeared that although plane of nutrition varied between rearings, there was always an 
Table 24.4 FOOD LEVELS AND THE ONSET OF OVARIAN ACTIVITY

\begin{tabular}{|c|c|c|c|c|c|c|}
\hline \multirow{2}{*}{$\begin{array}{l}\text { Plane of } \\
\text { nutrition }\end{array}$} & \multirow{2}{*}{$\begin{array}{l}\text { Weight gain } \\
(\mathrm{kg}) \\
\text { Oct. } \rightarrow \text { Dec. }\end{array}$} & \multicolumn{5}{|c|}{ Onset of cyclic activity (no. of animals) } \\
\hline & & $\overline{\text { Dec. } 11-17}$ & Dec. 18-24 & Dec. $25-31$ & Jan. $1-7$ & Jan. $8-14$ \\
\hline $\begin{array}{l}\text { I } \\
\text { II }\end{array}$ & $\begin{array}{l}2.2 \pm 0.9 \\
7.1 \pm 1.4\end{array}$ & $\overline{6}$ & - & 6 & 3 & \\
\hline
\end{tabular}

Group I: 9 animals receiving a control diet of $1 \mathrm{~kg}$ of a commercial pelleted food and $0.5 \mathrm{~kg}$ of barley or corn/animal/day.

Group II: 6 animals recciving $1.5 \times$ the amount given to the control group.

anoestrous period whose minimum duration extended from July to September. The onset of sexual activity was never observed before the beginning of October. To define nutritional effects more precisely, two planes of nutrition were tested in females kept in enclosures (Table 24.4). The onset of sexual activity occurred earlier in the females which were fed liberally (i.e. $1.5 \times$ the control level).

In the forest, availability of food fluctuates throughout the year and the onset of the breeding season occurs between the months of October and January. Data on the first incidence of fertile matings, collected over eight years, are presented in Table 24.5. It appears that earliness or delay in the onset of the breeding season (October or January) is related to the level of mast production in the forest in the autumn.

Table 24.5 ONSET OF BREEDING SEASON IN THE WILD BOAR POPULATION IN RELATION TO THE PRODUCTIVITY OF THE FOREST IN AUTUMN

\begin{tabular}{lllc}
\hline Year & Mast index $^{(\mathrm{a})}$ & Onset of breeding & \\
\hline 1972 & 2 & Nov.-Dec. & No. animals $^{(\mathrm{c})}$ \\
1973 & 4 & Oct.-Nov. & 16 \\
1974 & 2 & Dec.-Jan. & 401 \\
1975 & 1 & Dec.-Jan. & 229 \\
1976 & 3 & Oct.-Nov. & 58 \\
1977 & 1 & Dec.-Jan. & 117 \\
1978 & 4 & Oct.-Nov. & 74 \\
\hline
\end{tabular}

(a) 1-4: Autumn mast estimates from minimum to maximum productivity.

(b) Month during which more than $10 \%$ of females were bred.

(c)Total number of trapped animals under observation cach year.

It seems likely that nutritional factors may, in part, influence the timing of reproduction in the wild boar. Nutritional problems have been widely studied in the sow (e.g. reviews in Cole, 1972). Food levels mainly influence reproductive performance. In wild animals, low food availability has been reported often to cause a delay in puberty attainment or in the onset of sexual season (Sadleir, 1969). For example, this has been shown in the bear (Rogers, 1976) and in the white-tailed deer (Verme, 1965).

\section{SOCIAL FACTORS}

As reported above (p.513), births in the population of the forest can be spread over several months. However, within each social group, constituted by the association of a small number of females (about 4), a close synchronization of births is found generally within $10-15$ days. This reflects 
Table 24.6 FIRST FERTILE MATINGS AFTER THE ANOESTROUS PERIOD FOR THREE REARING GROUPS

\begin{tabular}{llccccccccc}
\hline Group & No. of females & \multicolumn{8}{c}{ Mating dases (day of the year) } \\
& & \multicolumn{10}{c}{ No. of first mating } \\
\hline I & 19 & 311 & 312 & 315 & 319 & 321 & 341 & 342 & 344 \\
II & & 2 & 2 & 2 & 1 & 1 & 3 & 3 & 5 \\
& 19 & 349 & 351 & 352 & 353 & 356 & 357 & & \\
III & 14 & 5 & 3 & 3 & 2 & 4 & 2 & & & \\
& & 337 & 338 & 340 & 357 & & & & & \\
\hline
\end{tabular}

a synchronization of the onset of the breeding season for females of the same social group.

In groups of females in rearing units, a similar synchronization of the onset of cyclic activity after the anoestrous period is also found. Thus, from the data presented in Table 24.6 it appears that the return to oestrus in each rearing.group occurs within about a week.

\section{PHOTOPERIOD}

The cessation of breeding seems to be independent of plane of nutrition as it is even observed under stable feeding conditions. Furthermore, the cessation of ovarian activity begins in mid-April, when environmental temperatures are still low (mean: $10.2^{\circ} \mathrm{C}$ ). This suggests the involvement of a reliable yearly environmental factor which might be photoperiod.
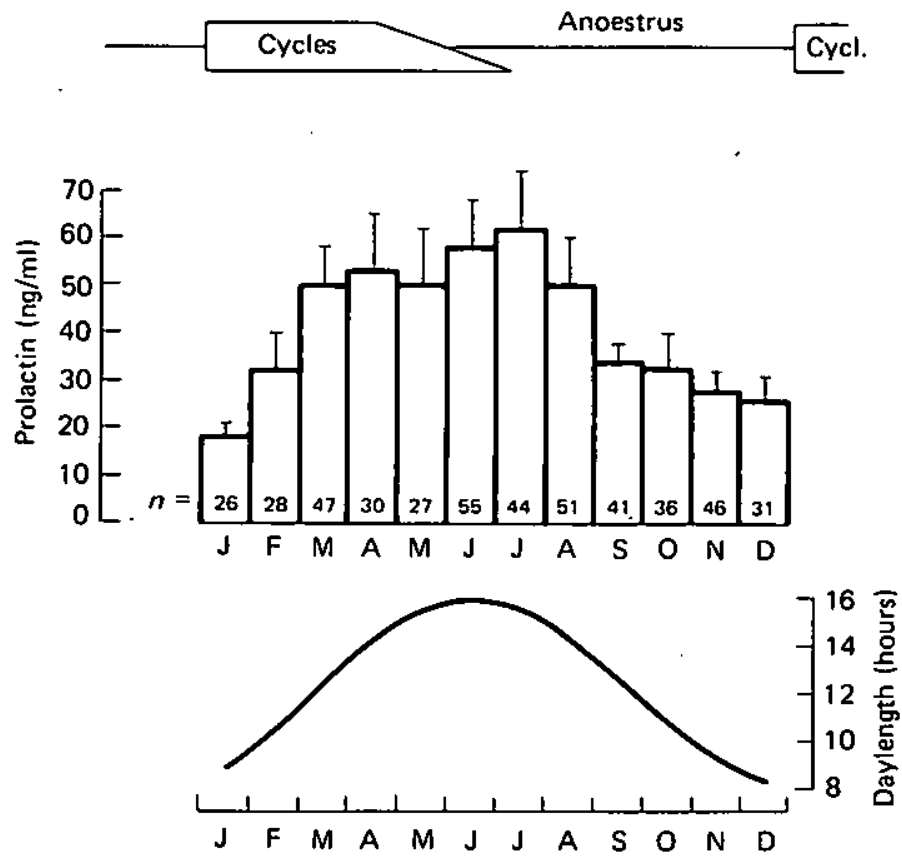

Figure 24.6 Seasonal variations of plasma prolactin levels (monthly pooled data of $n$ samples obtained from 16 animals) related to daylength variations and timing of reproduction. The $95 \%$ confidence intervals are indicated by the vertical lines 

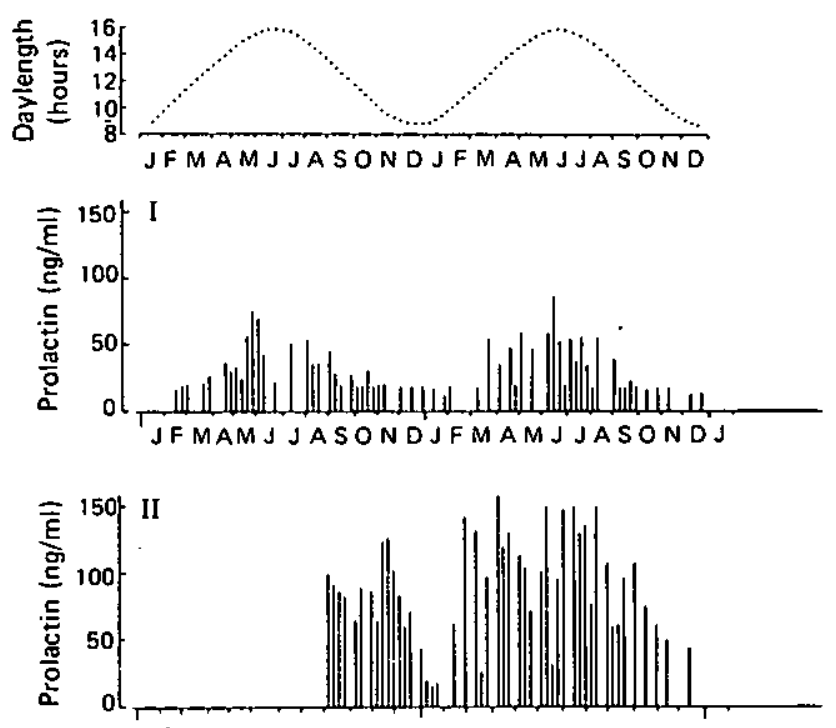

JFMAMJJASONDJFMAMJJASONDJ

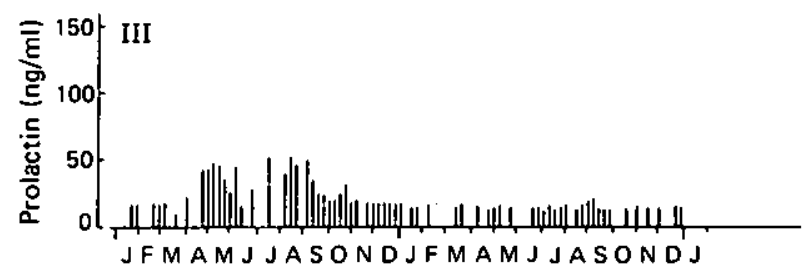

Figure 24.7 An illustration of marked individual fluctuations in prolactin profiles. (Frequency of each type: I = 11 animals, II $=3$ animals, III $=2$ animals)

The sensitivity of the wild boar to the annual variations of photoperiod has been indirectly investigated by studying seasonal changes in plasma prolactin concentrations. The results of monthly determinations of plasma prolactin levels are shown in Figure 24.6. A seasonal rhythm appears with peak values occurring in summer and minimum values in winter following the seasonal changes in natural daylength. Individual prolactin profiles are given in Figure 24.7, which shows marked individual fluctuations. While most females exhibit a pattern similar to the one shown for the pooled data, some deviations are observed. They relate to peak values reaching $180 \mathrm{ng} / \mathrm{ml}$ in some animals, while others have an annual prolactin profile that remains flat and at a low level. Stressful effects related to handling and venepuncture might be involved in increased prolactin levels, as has been reported in cattle (Raud, Kiddy and Odell, 1971; Leining, Bourne and Tucker, 1979). Nevertheless, it may be considered that over the two years of the study, the animals had adjusted to the sampling routine.

A relationship between the photoperiod and prolactin has been reported in many domestic ungulates e.g. cattle (Karg and Schams, 1974; Leining, Bourne and Tucker, 1979), goats (Buttle, 1974; Hart, 1975) and sheep (Pelletier, 1973; Lamming, Moseley and McNeilly, 1974; Ravault, 1976; 
Walton et al., 1977; Thimonier, Ravault and Ortavant, 1978). Manipulations of natural daylength have clearly demonstrated that the seasonal prolactin rhythm is primarily determined by photoperiod. Recent studies have shown similar prolactin rhythms in wild mammals such as the white-tailed deer (Mirarchi et al., 1978; Schulte et al., 1980), the badger, the red fox (Maurel, 1981) and the roe deer (Sempéré, 1982). In the domestic pig, values during different reproductive stages (e.g. oestrus and lactation) have been established (Brinkley, Wiltinger and Young, 1973; Van Landeghem and Van de Wiel, 1978; Bevers, Willemse and Kruip, 1978). The only study of long duration is that conducted by Ravault $e t$ al., 1981. It has been shown that both in the cyclic and spayed sows mean plasma prolactin concentrations were low throughout the year. However, a trend to seasonal variations has been shown with prolactin levels being slightly higher during the spring and summer months and the lowest values occurring from September to December. This feature might be interpreted as a 'vestige' of an ancestral photoperiodic rhythm which could reflect the seasonal prolactin rhythm reported in the wild species.

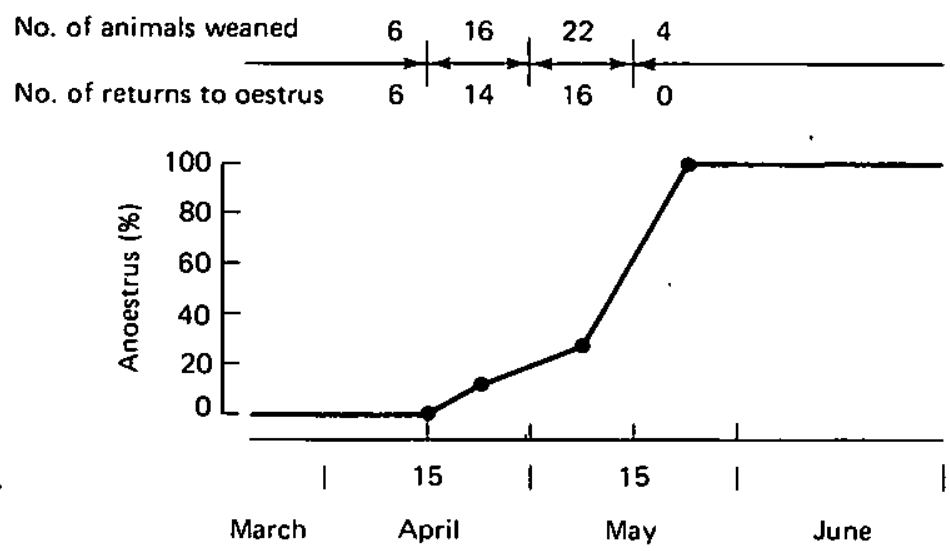

Figure 24.8 Occurrence of anoestrus in relation to time of weaning

In order to appreciate the seasonal influence, the natural timing of gestation and lactation were altered and the return to cyclic ovarian activity rccorded (Figure 24.8). When abortion or weaning occur before mid-April, they are always followed by a return to oestrus. When weaning occurs from 15th April to 15th May, a maximum of $75 \%$ of females exhibit subsequent ovarian cyclic activity. A post-weaning oestrus does not occur in later weaned females. The change to cessation of ovarian cyclic activity in

Table 24.7 THE CHANGE TO CESSATION OF OVARIAN CYCLIC ACTIVITY IN UNBRED FEMALES (NUMBER OF FEMALES)

\begin{tabular}{|c|c|c|c|c|c|c|c|c|}
\hline & \multicolumn{8}{|c|}{ Period of the year } \\
\hline & $1-15$ & $\begin{array}{l}\text { April } \\
16-30\end{array}$ & $1-15$ & $\begin{array}{l}\text { May } \\
16-31\end{array}$ & $1-15$ & $\begin{array}{l}\text { June } \\
16-30\end{array}$ & $1-15$ & $\begin{array}{c}\text { July } \\
16-31\end{array}$ \\
\hline $\begin{array}{l}\text { Cycling } \\
\text { In anoestrus } \\
\text { Cumulative (\%) }\end{array}$ & $\begin{array}{r}16 \\
0\end{array}$ & $\begin{array}{r}15 \\
1 \\
16)^{1}\end{array}$ & $\begin{array}{c}11 \\
5 \\
(31)\end{array}$ & $\begin{array}{l}8 \\
8 \\
(50)\end{array}$ & $\begin{array}{l}6 \\
10 \\
(62)\end{array}$ & $\begin{array}{l}3 \\
13 \\
(81)\end{array}$ & $\begin{array}{l}1 \\
15 \\
(94)\end{array}$ & $\begin{array}{l}0 \\
16 \\
(100)\end{array}$ \\
\hline
\end{tabular}


unbred females exhibits a similar progressive pattern (Table 24.7). The cumulative percentage of animals in anoestrus increases slightly from mid-April and reaches $100 \%$ in July.

If the present data suggest that the wild boar is photoperiodic with respect to reproduction, then further investigations of the physiological mechanisms responsible for the seasonality of breeding are necessary. It is not known whether a relationship exists between increased prolactin levels and cessation of ovarian activity. From the literature, the effects of prolactin remain controversial. Hyperprolactinaemia has been correlated with a reduction of both gonadotrophin secretion and ovarian steroidogenesis in rats (Beck et al., 1977), women (Rolland et al., 1975; McNatty, Sawers and McNeilly, 1974) and sheep (Kann, Martinet and Schirar, 1978; Munro, McNatty and Renshaw, 1980). Other studies have failed to provide evidence of antigonadotrophic effects of prolactin in ewes (Niswender, 1974; Schanbacher, 1980) and bovine heifers (Williams and Ray, 1980). As stated by Walton et al. (1980) it seems unlikely that prolactin levels per se are solely responsible for seasonal effects on ovarian activity. The internal mechanisms involved in the seasonal pattern of reproduction in the wild boar might be similar to those developed in other seasonal breeders. Present theories (Turek and Campbell, 1979; Karsch, Goodman and Legan, 1980) suggest that the feedback interplay between gonadal hormones and gonadotrophin is seasonally modified by a photoperiodic alteration of hypothalamic-pituitary activity.

\section{Conclusions}

The data presented here support the evidence of an environmental control of reproductive activity in the wild boar. As schematically represented in Figure 24.9, a number of environmental factors, whose relative importance

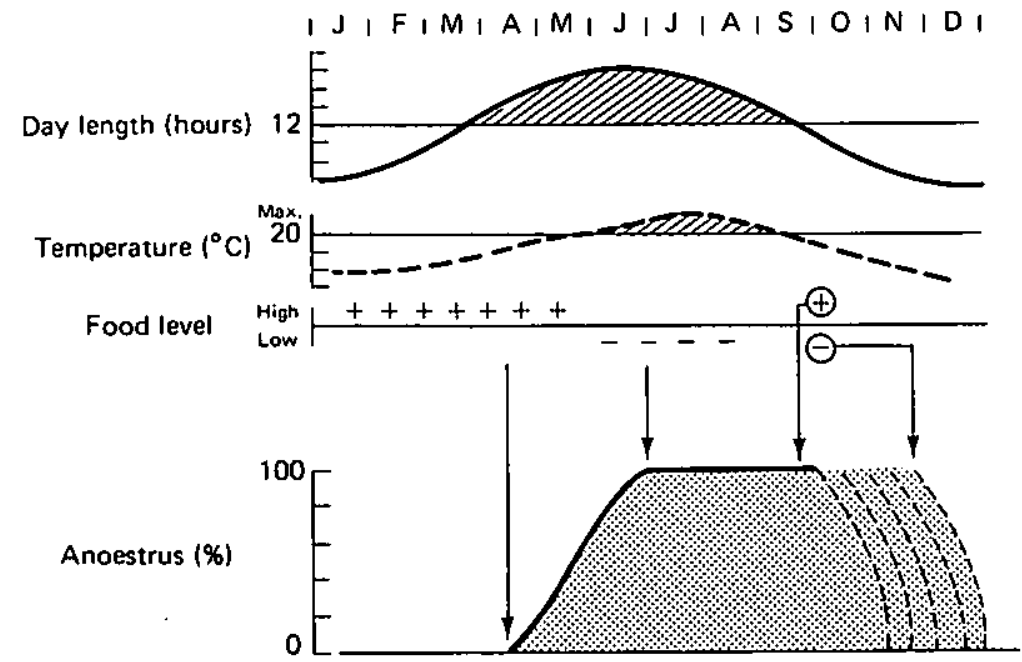

Figure 24.9 Seasonal changes in environmental factors and reproductive activity in the European wild boar 
is different may be involved at the cessation and at the onset of the sexual season.

From April to June, the frequency of anoestrus increases progressively. It begins prior to the onset of high environmental temperatures and during a period of relatively high food availablity. This led to the consideration of the influence of the factor showing greatest change, namely, daylight increasing from 12 to 16 hours. The progressive nature of the response may be related to individual variations of sensitivity.

From July to September, the whole population is anoestrous. All the external stimuli may act as limiting factors during this period, i.e. more than 12 hours daylight, external temperature over $20^{\circ} \mathrm{C}$ and low summer food availability.

From October, the onset of the breeding season can be regulated by the availability of food. Depending on annual variations in mast availability in the autumn, cyclic activity occurs early (October) or is delayed (Decem. ber). Subsequently, there can be either one or two litters per year.

Thus, the sensitivity of the European wild boar to its environment allows the synchronization of reproduction at the most advantageous time of the year. The seasonal anoestrus, the length of which determines the frequency of breeding, appears to be the major mechanism controlling the dynamics of the natural population. In modern breeds of domestic pig, this adaptative quality has disappeared although a trend to a summer reproductive inefficiency does persist and may reflect the dependence of reproduction on environmental factors that have been described for the wild boar.

\section{References}

ASDElL S.A. (1964). Patterns of Mammalian Reproduction. New York, Cornell University Press

ASSENMACHER 1. (1974). External and internal components of the mechanism controlling reproductive cycles in drakes. Circannual Clocks (E.T. Pingelley, Ed.), pp. 197-239. New York, Academic Press

ASSENMACHER I. and FARNER D.S. (Eds.) (1978). Environmental Endocrinology. Berlin, Heidelberg and New York, Springer Verlag

BAL H.S., WENSING C.J.G. and GETTY R. (1969). Morphological changes in the vaginal epithelium and ovary of swine of various ages as a mean of evaluating cyclic phases. lowa State J. Sci. 43, 341-358

BARRETT R. (1978). The feral hog on the Dye Creek Ranch, California. Hilgardia 46, 283-355

BECK W., ENGELBART S., GELATO M. and WUTTKE w. (1977). Antigonadotrophic effects of prolactin in adult castrated and in immature female rats. Acta endocr. 84, 62-71

BEVERS M.M., WILLEMSE A.H. and KRUIP T.A.M. (1978). Plasma prolactin levels in the sow during lactation and the postweaning period as measured by radioimmunoassay. Biol. Reprod. 19, 628-634

BRIEDERMAN I. (1971). Zur Reproduction des Schwarzwildes in der Deutschen Demokratischen Republik. TagBer, dt. Akad. LandwWiss. Berl. 113, 169-186 
BRINKLEY H.J., WILFINGER, W.W. and YOUNG E.P. (1973). Plasma prolactin in the estrous cycle of the pig. J. Anim. Sci. 37, 303

BUTTLE H.L. (1974). Seasonal variation of prolactin of male goats. $J$. Reprod. Fert. 37, 95

COLE D.J.A. (1972). Pig Production. London, Butterworths

CORNER G.W. (1921). Cyclic changes in the ovaries and uterus of the sow and their relation to mechanism of implantation. Contr. Embryol. 13, 117-146

CORTEEL, J.M., SIGNORET J.P. and DU MESNIL DU BUISSON F. (1964). Variations saisonnières de la reproduction de la Truie et facteurs favorisant l'anoestrus temporel. 5th Congr. Int. Reprod. Anim. Insem. Artif., Trente 3, 536-546

DUNCAN R.W. (1974). Reproductive biology of the european wild hog in the Great Smoky Mountains National Park. M.S. Thesis. University of Tennessee

EDQVIST L.E. and LAMM A.M. (1971). Progesterone levels in plasma during the oestrous cycle of the sow, measured by a rapid competitive protein binding technique. J. Reprod. Fert. 25, 447-449

ENNE G., BECCARO P.V. and TAROCCO C. (1979). A note on the effect of climate on fertility in pigs in the Padana valley of Italy. Anim. Prod. 28, 115-117

Haber A. (1969). Dzik. Panstw. Wyd. Roln i Lesn., Warsaw, 1-215

HAGEN D.R. and KEPHART K.B. (1980). Reproduction in domestic and feral swine. I. Comparison of ovulatory rate and litter size. Biol. Reprod. 22, . $550-552$

HALBERG F., JOHNSON E.A., NELSON W., RUNGE W. and SOTHERN R. (1972). Autorhythmometry: Procedures for physiologic self-measurements and their analysis. Physiol. Teacher 1, 3-11

HART I.C. (1975). Concentrations of prolactin in serial blood samples from goats before, during and after milking throughout lactation. $J$. Endocr. 64, 305-312

HENRICKS D.M., GUTHRIE H.D. and HANDLIN D.L. (1972). Plasma estrogen, progesterone and luteinizing hormone levels during the estrous cycle in pigs. Biol. Reprod. 6, 210-218

HENRY V.G. (1968). Length of estrous cycle and gestation in European wild hogs. J. Wildl. Mgmt. 32, 406-408

HURTGEN J.P. (1976). Seasonal anestrus in a Minnesota swine breeding herd. Proc. 4th Int. Pig Vet. Soc., D 22

HURTGEN J.P., LEMAN A.D. and CRABO B. (1980). Seasonal influence on estrous activity in sows and gilts. $J$. Am. vet. med. Ass. 176, 119-123

KANN G., MARTINET J. and SCHIRAR A. (1978). Hypothalamic-pituitary control during lactation in sheep. In Control of Ovulation, (D.B. Crighton, N.B. Hayes, G.R. Foxcroft and G.E. Lamming, Eds.), pp. 319-333. London, Butterworths

KARG H. and SCHAMS D. (1974). Prolactin release in cattle. J. Reprod. Fert. $39,463-472$

KARSCH F.J., GOODMAN R.L. and LEGAN S.J. (1980). Feedback basis of seasonal breeding : test of an hypothesis. J. Reprod. Fert. 58, 521-535

LAMMING G.E., MOSELEY S.R. and McNEILLY J.R. (1974). Prolactin release in the sheep. J. Reprod. Fert. 40, 151-168 


\section{Seasonality of reproduction in the wild boar}

LEINING K.B., BOURNE R.A. and TUCKER H.A. (1979). Prolactin response to duration and wavelength of light in prepubertal bulls. Endocrinology 104, 289-294

McFEE A.F., BANNER H.W. and RARY J.H. (1966). Variation in chromosome number among European wild pigs. Cytogenetics 5, 75-81

McNATTY K.P., SAWERS R.S. and McNEILLY A.S. (1974). A possible role for prolactin in control of steroid secretion by the human graafian follicle. Nature, Lond. 250, 653-655

MAUGET R. (1972). Observations sur la reproduction du Sanglier (Sus scrofa L.) à l'état sauvage. Ann. Biol. anim. Biochem. Biophys. 12, 195-202

MAUGET R. (1978). Seasonal reproductive activity of the european wild boar; comparison with the domestic sow. In Environmental Endocrinology, (I. Assenmacher and D.S. Farner, Eds.), pp. 79-80. Berlin, Heidelberg and New York, Springer Verlag

MAUGET R. (1980). Régulations écologiques, comportementales et physiologiques (reproduction) de l'adaptation du Sanglier, Sus scrofa, au milieu. Doct. Thesis. University of Tours

MAUGET R., BOISSIN-AGASSE L. and BOISSIN J. (1981). Ecorégulatin du cycle de la fonctin de reproduction chez les Mammifères sauvages. Bull. Soc. Zool. France 106, 431-443

MAUGET R., CASTET M.C., MARAUD C. and CANIVENC R. (1977). Etude dynamique et caryotypique d'une population de sangliers à robe claire. C.r. Soc. Biol. 171, 592-596

MAUREL D. (1981). Variations saisonnières des fonctions testiculaire et thyroidienne en relation avec l'utilisation de l'espace et du temps chez le Blaireau européen (Meles meles) et le Renard roux (Vulpes vulpes). Doct. Thesis. University of Montpellier

MENAKER M., TAKAHASHI, J.S. and ESKIN A. (1978). The physiology of circadian pace makers. Ann. Rev. Physiol. 40, 501-526

MIRARCHI R.E., HOWLANDS B.E., SCANLON P.F., KIRKPATRICK R.L. and SANFORD L.M. (1978). Seasonal variation in LH, FSH, prolactin, and testosterone concentrations in adult male white tailed deer. Can. $J$. Zool. 56, 121-127

MOLENAT M. and CASABIANCA F. (1979). Contribution à la maîtrise de l'élevage porcin extensif en Corse, I.N.R.A., Bull. Tech. Dept. Gent. Anim. 32, $72 \mathrm{pp}$

MUNRO C.J., MCNATTY K.P. and RENSHAW L. (1980). Circa-annual rhythms of prolactin secretion in ewes and the effect of pinealectomy. J. Endocr. 84, 83-89

NISWENDER G.D. (1974). Influence of 2-Br- $\alpha$-ergocryptine on serum levels of prolactin and the estrous cycle in sheep. Endocrinology 94, 612-615

OLOFF H.B. (1951). Zur biologie und ökologie des wildschweines. Beitr. Tierk. Tierz. 2, 1-95

PATERSON A.M., BARKER I. and LINDSAY D.R. (1978). Summer infertility in pigs: its incidence and characteristics in an Australian commercial piggery. Aust. J. exp. Agric. Anim. Husb. 18, 698-701

PELLETIER J. (1973). Evidence for photoperiodic control of prolactin release in rams. J. Reprod. Fert. 35, 143-147 
PERRY J.S. and ROWLANDS I.W. (1973). The environment and reproduction in mammals and birds. J. Reprod. Fert., Suppl. 19

PINE D.S. and GERDES G.L. (1973). Wild pigs in Monterey County California. Calif. Fish Game 59, 126-137

RADEV G., ANDREEV A. and KOSTOV L. (1976). The influence of age and season on the weaning to oestrus period in sows. Proc. Intern. Congr. Anim. Reprod. Artif. Insem., Krakow, 1, Communication Abstracts, 208

RAUD H.R., KIDDY C.A. and ODELL W.D. (1971). The effect of stress upon the determination of serum prolactin by radioimmunoassay. Proc. Soc. exp. Biol. Med. 136, 689

RAVAULT J.P. (1976). Prolactin in the ram: seasonal variations in the concentration of blood plasma from birth until three years old. Acta endocr. (Kbh) 83, 720-725

RAVAULT, J.P. (1981). (to be published)

ROGERS L.L. (1976). Effects of mast and berry crop failures on survival, growth and reproductive success of black bears. Trans. N. Am. Wildl. Conf. 41, 431-437

ROLLAND R., LEQUIN R.M., SCHELLEKENS L.A. and DE JONG F.H. (1975). The role of prolactin in restoration of ovarian function during the early post-partum period in the human female. 1. Clin. Endocr. 4, 15-25

SADLEIR R.M.F.S. (1969). The role of nutrition in the reproduction of wild mammals. J. Reprod. Fert., Suppl. 6, 39-48

SCHANBACHER B. (1980). Relationship of daylength and prolactin to resumption of reproductive activity in anestrous ewes. J. Anim. Sci. 50, 293-297

SCHULTE B.A., PARSONS J.A., SEAL U.S., PLOTKA E.D., VERME L.J. and OZOGA J.J. (1980). Heterologous radioimmunoassay for deer prolactin. Gen. Comp. Endocrinol. 40, 59-68

SEMPERE, A. (1982). Fonction de reproduction et caractères sexuels secondaires chez la chevreuil (Capreolus capreolus L.): variations saisonnières et incidences sur l'utilisation du budget temps-espace. Doct. Thesis, University of Tours

SHEARER I.J., PURVIS K., JENKIN G. and HAYNES N.B. (1972). Peripheral plasma progesterone and estradiol-17 $\beta$ levels before and after puberty in gilts. J. Reprod. Fert. 30, 347-360

SNETHLAGE K. (1974). Das Schwarzwild. Berlin, Paul Parey Verlag

STABENFELDT G.H., AKINS E.L., EWING L.L. and MORRISSETTE M.C. (1969). Peripheral plasma progesterone levels in pigs during the oestrus cycle. $J$. Reprod. Fert. 20, 443-449

STEINBACH J. and SCHMIDT D. (1970). Cyclical phenomena in the female genital tract of swine. Histological observations. J. Anim. Sci. 30, 573-577

STORK M.G. (1979). Seasonal reproductive inefficiency in large pig breeding units in Britain. Vet. Rec. 104, 49-52

THIMONIER J., RAVAULT J.P. and ORTAVANT R. (1978). Plasma prolactin variations and cyclic ovarian activity in ewes submitted to different light regimens. Ann. Biol. anim. Biochem. Biophys. 18, 1229-1235

TILLSON S.A., ERB R.E. and NISWENDER G.D. (1970). Comparison of luteinizing hormone and progesterone in blood and metabolites of progesterone in urine of domestic sows during the oestrous cycle and early pregnancy. J. Anim. Sci. 30, 795 
. TUREK F.W. and CAMPBELl. (1979). Photoperiodic regulation of neuroendocrine-gonadal activity. Biol. Reprod. 20, 32-50

VAN LANDEGHEM, A.A.J. and VAN DE WIEL. D.F.M. (1978). Radioimmunoassay for porcine prolactin: plasma levels during lactation, suckling and weaning and after TRH administration. Acta endocr. 88, 653-667

VERME L.J. (1965). Reproductive studies in penned white tailed deer. $J$. Wildl. Mgmt. 29, 74-79

WALTON J.S., EVINS J.D., FITZGERALD B.P. and CUNNINGHAM F.J. (1980). Abrupt decrease in daylength and short-term changes in the plasma concentrations of FSH, LH and prolactin in anoestrous ewes. J. Reprod. Fert. 59, 163-171

WALTON J.S., McNEILLY J.R., McNEILLY A.S. and CUNNINGHAM F.J. (1977). Changes in concentrations of $\mathrm{FSH}, \mathrm{LH}$, prolactin and progesterone in the plasma of ewes during the transition from anoestrus to breeding activity. $J$. Endocr. 75, 127-136

WILLIAMS G.L. and RAY D.E. (1980). Hormonal and reproductive profiles of early postpartum beef heifers after prolactin suppression or steroidinduced luteal function. J. Anim. Sci. 50, 906-918 